[Short Report]

\title{
Nuclear Factor-kappa B Is Not Involved in Titanium Dioxide- Induced Inflammation
}

Donald Wilson ${ }^{1}$, Mazen Zaqout ${ }^{1}$, Jeong-Hoon $\mathrm{HeO}^{2}$, Eun-Kee PARK ${ }^{3}$, Chul-Ho OAK ${ }^{4}$ and Susumu UENO ${ }^{1}$

${ }^{1}$ Department of Occupational Toxicology, Institute of Industrial Ecological Sciences, University of Occupational and Environmental Health, Japan. Yahatanishi-ku, Kitakyushu 807-8555, Japan

${ }^{2}$ Department of Molecular Biology \& Immunology, Kosin University College of Medicine, Busan 602-702, Korea

${ }^{3}$ Department of Medical Humanities and Social Medicine, Kosin University College of Medicine, Busan 602-702, Korea

${ }^{4}$ Department of Respiratory Medicine, Kosin University, Korea, Kosin University College of Medicine, Busan 602-702, Korea

\begin{abstract}
Research over recent years have shown that titanium dioxide $\left(\mathrm{TiO}_{2}\right)$ nanoparticles (NPs) induce inflammation in various lung, kidney, liver and brain cells. Although the mechanism of inflammation is unclear, existing literature suggests the underlying role of oxidative stress. On the other hand, it has also been shown that nuclear factor-kappa B (NF$\kappa \mathrm{B})$ is activated in response to pro-inflammatory cytokines. In this study we investigated the involvement of $\mathrm{NF}-\kappa \mathrm{B}$ in $\mathrm{TiO}_{2}$-induced inflammation in human lung adenocarcinomic epithelial cells (A549 cells). After 24h of treatment, IL-8 protein release from A549 cells, induced by 10,50 and $250 \mu \mathrm{g} / \mathrm{ml}$ of $\mathrm{P} 25 \mathrm{TiO}_{2} \mathrm{NPs}$, were statistically significantly raised, compared to that of the control. This finding corroborates existing literature in that $\mathrm{TiO}_{2}$ NPs induce a dose-dependent increase in the release of IL-8 protein when exposed to A549 cells. However, the binding of NF-kB DNA was not affected after $6 \mathrm{~h}$ of incubation with P25. Therefore, NF-kB DNA binding is not the likely transcription pathway that leads to $\mathrm{TiO}_{2}-$ induced inflammation.
\end{abstract}

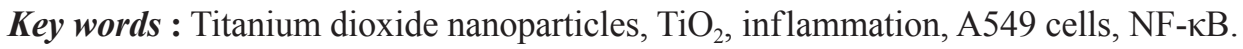

(Received February 15, 2012, accepted April 27, 2012)

*Corresponding Author : Donald Wilson, MD, PhD, Department of Occupational Toxicology, Institute of Industrial Ecological Sciences, University of Occupational and Environmental Health, Japan. Yahatanishi-ku, Kitakyushu 807-8555, Japan, Tel : +81-093-691-7404, Fax : +81-093-692-4790, E-mail: wilson@med.uoeh-u.ac.jp 


\section{Introduction}

Titanium dioxide $\left(\mathrm{TiO}_{2}\right)$, a noncombustible and odorless white powder, exists naturally in the forms of anatase, rutile and brookite. However, its more familiar form is as a white pigment for a wide range of paints, paper, plastics, ceramics, etc. $\mathrm{TiO}_{2}$ becomes transparent at the nanoscale (particle size $<100 \mathrm{~nm}$ ), is able to absorb and reflect UV light, and has consequently been popularly used in sunscreen lotions and creams. In addition, nano-sized $\mathrm{TiO}_{2}$ is nowadays produced abundantly and used widely because of its high stability and its anti-corrosive and photocatalytic properties [1]. Due to the extensive use of $\mathrm{TiO}_{2}$, and the fact that nano-sized particles are generally more toxic than their larger-sized counterparts [2], concern for the potential risk of $\mathrm{TiO}_{2}$ nanoparticles (NPs) to humans has increased.

Based on the recommendations of the International Agency for Research on Cancer (IARC) [1], the U.S. National Institute for Occupational Safety and Health (NIOSH) recently deemed inhaled ultrafine or nano-sized $\mathrm{TiO}_{2}$ a potential occupational carcinogen, and has consequently recommended exposure limits to minimize the cancer risk from exposure to ultrafine $\mathrm{TiO}_{2}$ [3] . The NIOSH also suggested that the most plausible mechanism for $\mathrm{TiO}_{2}$ carcinogenesis is a nonspecific chemical interaction of the particle with the cells in the lung, characterized by persistent inflammation and mediated by secondary genotoxic processes [3].

$\mathrm{TiO}_{2}$ NPs have been shown to induce inflammation in exposed cell lines. A study by Singh et al (2007) demonstrated that only the nano-sized $\mathrm{TiO}_{2}$ particles [4], and not the slightly larger "fine" particles, were found to elicit oxidative stress and IL-8 release from A549 cells. In addition, this $\mathrm{TiO}_{2}$-induced inflammation in A549 cells was proportional to the particle surface area that was exposed, suggesting that a large surface area alone in the lung may be sufficient to initiate inflammation by particles [5]. Although the mechanism of inflammagenicity induced by $\mathrm{TiO}_{2} \mathrm{NPs}$ remains unclear, previous studies suggest that oxidative stress should be considered as an event that underlies and regulates cellular signaling that leads to inflammatory, proliferative, and genotoxic effects of particle substances [6].

Activation of nuclear factor-kappa B (NF- $\mathrm{B})$ has also been shown in human peripheral blood mononuclear cells, airway epithelial cells and lung tissue in response to pro-inflammatory cytokines [7]. This research group also suggested that activation of NF- $\mathrm{BB}$ occurs through the generation of reactive oxygen species (ROS). We wanted to investigated in this study whether the $\mathrm{TiO}_{2}$ NPs-induced inflammogenicity is caused by oxidative-stress-driven DNA damage, via overexpression of NF- $\mathrm{BB}$ in human lung epithelial cells.

\section{Materials and methods}

\section{Particle preparation and characterization}

P25 $\mathrm{TiO}_{2}$ nanoparticles (BET specific surface area of $53.8 \mathrm{~m}^{2} / \mathrm{g}$ ) were obtained from Degussa. Crystalline silica (Min-U-Sil 5) quartz (BET specific surface area of $5 \mathrm{~m}^{2} / \mathrm{g}$ ) was used as a positive control. The particles were suspended as follows: 1.5 grams of $\mathrm{P} 25 \mathrm{TiO}_{2}$ powder was suspended in $100 \mathrm{ml}$ of distilled water, and sonicated for 15 minutes by a Branson Digital 
Cell Disruptor Sonifier 250; this process was repeated 3 times. The particle suspension was then centrifuged at $3,000 \times \mathrm{g}$ for 20 minutes, at $20^{\circ} \mathrm{C}$. The supernatant was carefully collected and filtered through a $1 \mu \mathrm{m}$ filter to remove the large agglomerates $(>1 \mu \mathrm{m})$. A given volume of particle suspension was evaporated, after which the weight of the remaining evaporate was measured and the $\mathrm{P} 25 \mathrm{TiO}_{2}$ concentration determined (w/v; in $\mathrm{mg} / \mathrm{ml}$ ). Immediately before application to cells, the particle suspension was mixed with double-strength $(2 \times)$ serum free Dulbecco's Modified Eagle Medium (DMEM) and sonicated for 15 minutes in a water bath.

The hydrodynamic size distribution by number of $\mathrm{P} 25 \mathrm{TiO}_{2}$ particles suspended in water was analyzed using a DLS Zetasizer Nano (Malvern Instruments, U.K.), and the average particle size was calculated to be $61.94 \pm 5.14 \mathrm{~nm}$ (Fig. 1). Because the particles that were ultimately treated with the A549 cells were suspended in serum free DMEM (SFM), we also tried to measure the hydrodynamic particle size of particles suspended in SFM. Unfortunately, because the suspensions were unstable, the results were inconclusive and therefore not used.

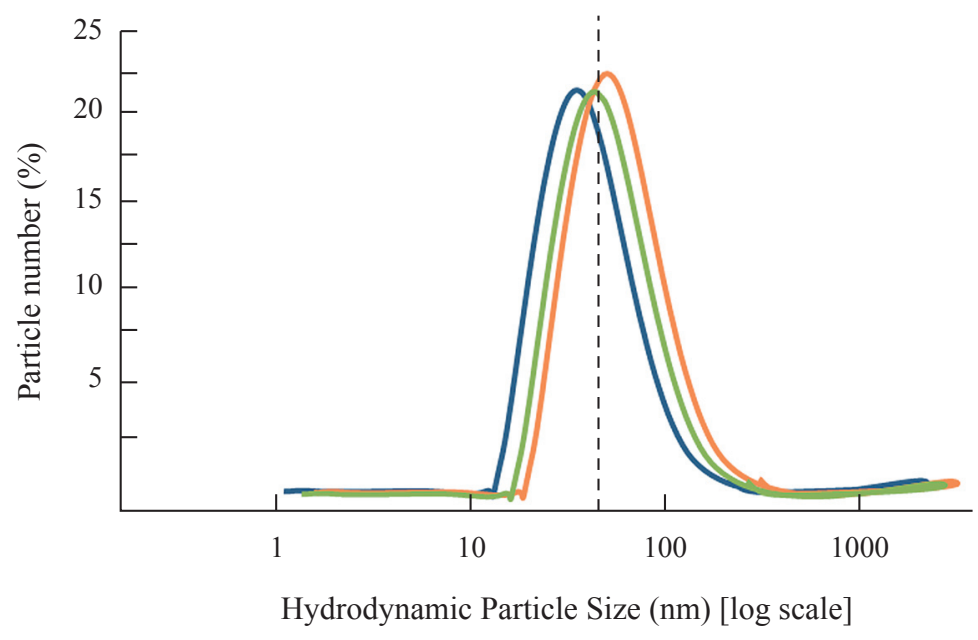

Fig. 1. Dynamic Light Scattering (DLS) spectra of the P25 titanium dioxide $\left(\mathrm{TiO}_{2}\right)$ nanoparticles (NPs) in water. The graph shows the logarithmic scale of the hydrodynamic particle size (nm) against the particle number (\%). $\mathrm{TiO}_{2}$ NPs were dispersed in ultrapure water, and sonicated 3 times for 15 minutes. After centrifugation, the supernatant was carefully collected and filtered. The hydrodynamic particle number and size distribution in water suspensions was analyzed for 3 samples of the same $\mathrm{TiO}_{2}$ concentration, using a DLS Zetasizer Nano (Malvern Instruments, U.K.). The three peaks on the graph are representative of the 3 samples, the average particle size of which was calculated to be $61.94 \pm 5.14 \mathrm{~nm}$ (represented by the dotted vertical line). 


\section{Cell culture and treatment}

Human long adenocarcinomic alveolar basal epithelial cells (A549 cells), were obtained from Keio University, Tokyo. The cells were maintained in DMEM (Invitrogen, Carlsbad, CA), supplemented with $10 \%$ fetal bovine serum (Hyclone, Logan UT), and $100 \mathrm{U} / \mathrm{ml}$ penicillin/streptomycin (Invitrogen) at $37^{\circ} \mathrm{C}$ and $5 \% \mathrm{CO}_{2}$. The cells were plated in 6 -well plates at a density of $1 \times 10^{5}$ cells /well.

For the assays, the cells were treated for 6, 12 or 24 hours, with $\mathrm{P} 25 \mathrm{TiO}_{2} \mathrm{NPs}$ at final concentrations of 2, 10, 50 and $250 \mu \mathrm{g} / \mathrm{ml}$, and with Min-U-Sil explained in p184 at final concentrations of $48,96,192$ and $384 \mu \mathrm{g} / \mathrm{ml}$. The cells were cultured to $80 \%$ confluency in DMEM with $10 \%$ fetal bovine serum (FBS) and then starved for 24 hours to arrest their growth before treatment.

\section{Measurement of IL-8 by ELISA}

Human IL-8 released from the cells was measured by Human IL-8 ELISA kit (Thermo Scientific, Rockford IL). Following incubation with the NPs for 24 hours, cell supernatants were recovered and centrifuged at $13,000 \times \mathrm{g}$ for 10 minutes and the particle-free cell supernatants were stored at $-80^{\circ} \mathrm{C}$ until analysis. ELISA was performed as described in the manufacturer's instructions. Briefly, $50 \mu \mathrm{l}$ of standard diluents or cell supernatants were added to an anti-human IL-8 pre-coated 96-well strip plate and incubated for 1 hour at room temperature. The plate was washed 3 times with Wash Buffer, and $50 \mu$ of the biotinylated antibody reagent was added to each well and incubated for 1 hour at room temperature. After washing 3 times with Wash Buffer, $100 \mu \mathrm{l}$ of streptavidin-HRP solution was added to each well and incubated for 30 minutes at room temperature. After washing 3 times with Wash Buffer, $100 \mu 1$ of 3,3',5,5'-Tetramethylbenzidine (TMB) solution was added to the well and incubated in a dark room for 30 minutes at room temperature. The reaction was stopped by adding $100 \mu 1$ of Stop Solution. Absorbance was measured on an ELISA plate reader at 450 and $550 \mathrm{~nm}$. Human IL-8 amounts were determined using the standard curve and expressed as $\mathrm{pg} / \mathrm{ml}$.

\section{$N F-\kappa B$ determination}

\section{Nuclei extraction}

After exposure of the cells to NPs, they were washed 3 times in ice-cold phosphate-buffered saline (PBS). The cells were scraped in PBS and then pelleted for 15 seconds at $14,000 \times \mathrm{g}$. The cells were re-suspended in $400 \mu \mathrm{l}$ of lysis buffer (10 mM 4-(2-hydroxyethyl)-1-piperazineethanesulfonic acid (HEPES), pH 7.8, $50 \mathrm{mM} \mathrm{KCl,} 2 \mathrm{mM} \mathrm{MgCl}_{2}, 1 \mathrm{mM}$ dithiothreitol (DTT), $0.1 \mathrm{mM}$ ethylenediaminetetraacetic acid (EDTA), $0.4 \mathrm{mM}$ phenylmethanesulfonylfluoride (PMSF), 0.2 $\mathrm{mM} \mathrm{NaF}, 0.2 \mathrm{mM}$ sodium Orthovanadate, $1 \mu \mathrm{g} / \mathrm{ml}$ Leapeptin) and incubated for 15 minutes on ice. $10 \% \mathrm{NP}-40$ were added to the mixture and then centrifuged at $14,000 \times \mathrm{g}$ for 30 seconds. The supernatant containing the cytoplasmic fraction was aspirated and retained. The pelleted nuclei were re-suspended in $50 \mu \mathrm{l}$ of extract, and mixed for 20 minutes by rotation, then centrifuged for 5 minutes at $14,000 \times \mathrm{g}$. The supernatant containing nuclear proteins was collected and saved for further Western blotting (WB) and electrophoretic mobility shift assay (EMSA). Protein concentrations were measured (by Bradford method) prior to saving the supernatant. 


\section{Electrophoretic mobility shift assay (EMSA)}

The NF- $\kappa$ B was determined by EMSA Kit (E33075 from Molecular Probes Invitrogen Detection Technologies), according to the manufacturer's instructions. Briefly, DNA-protein binding assays were carried out with the nuclear extract. Synthetic complementary NF- $\mathrm{B}$ (5'-AGT TGA GGG GAC TTT CCC AGG C-3') binding oligonucletides (Bioneer) were 3'-biotinylated using the biotin 3'-end DNA labeling Kit (Pierce) according to the manufacturer's instructions, and annealed for 30 minutes at room temperature. The reaction mixture was electrophoretically separated on a $4 \%$ polyacrylamide gel in $0.5 \mathrm{X}$ Tris-borate buffer and transferred to a nylon membrane. The transferred DNAs were cross-linked to the membrane at $120 \mathrm{~mJ} / \mathrm{cm}^{2}$. Horseradish peroxidase-conjugated streptavidin was use according to the manufacturer's instructions to detect the transferred DNA.

\section{Results}

\section{IL-8 release from $\mathrm{A} 549$ cells by $\mathrm{TiO}_{2} \mathrm{NPS}$}

When A549 cells were exposed to $\mathrm{TiO}_{2}$ NPs for 24 hours, the concentrations of IL-8 released in the culture medium were increased in a $\mathrm{TiO}_{2}$-dose dependent manner (Fig. 2). The increase of IL- 8 release induced by 10,50 and $250 \mu \mathrm{g} / \mathrm{ml}$ of $\mathrm{TiO}_{2}$ was statistically significant, compared to that of the control sample.

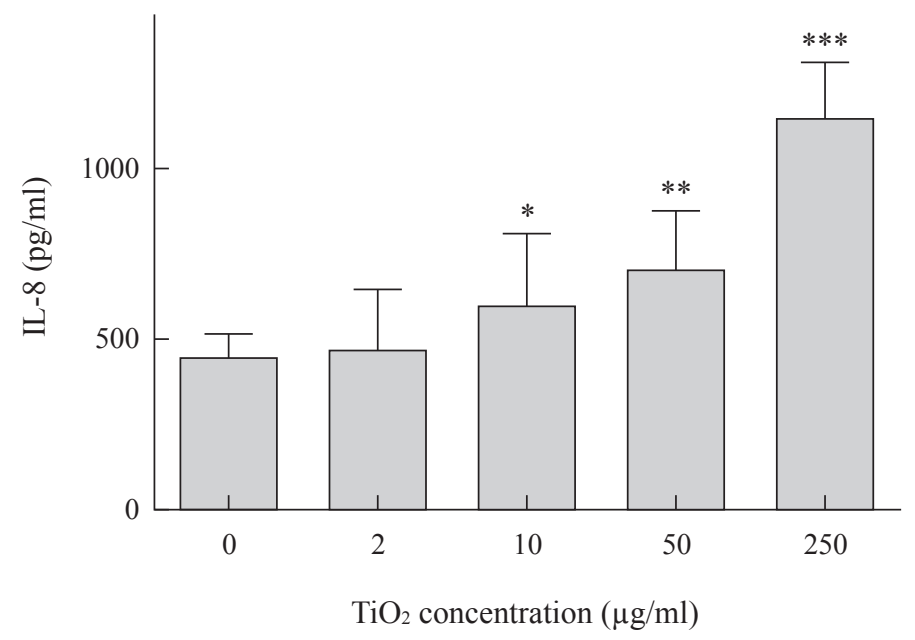

Fig. 2. IL-8 protein release from A549 cells, 24 hours after exposure to $\mathrm{TiO}_{2}$ NPs. After the A549 cells were treated with and without $\mathrm{TiO}_{2} \mathrm{NPs}$ for 24 hours, at concentrations of 2, 10,50 and $250 \mu \mathrm{g} / \mathrm{ml}$, the supernatant was collected and centrifuged at $13,000 \times \mathrm{g}$ for $10 \mathrm{~min}$. The concentrations of released IL-8 in the culture media were measured using Enzyme-linked immuno sorbent assay (ELISA) Kit. The amounts of IL-8 are expressed as mean \pm SD. Asterisks on bar graphs indicate statistically significant differences compared to the control (no $\left.\mathrm{TiO}_{2}\right)$, *: $P<0.05$, **: $P<0.01$ and ***: $P<0.001$ (one way ANOVA followed by the Dunnett's test). 
Effect of $\mathrm{TiO}_{2} \mathrm{NPS}$ on $\mathrm{NF}-\kappa \mathrm{B}$ DNA binding activity

The effect of $\mathrm{TiO}_{2}$ NPs exposure on NF- $\mathrm{BB}$ DNA binding was evaluated after 6 hours of exposure, when the expressions of NF- $\kappa \mathrm{B}$ bands were verified by EMSA. As shown in Fig. 3, $\mathrm{TiO}_{2}$ NPs did not affect the binding activity of NF- $\mathrm{B}$ DNA.

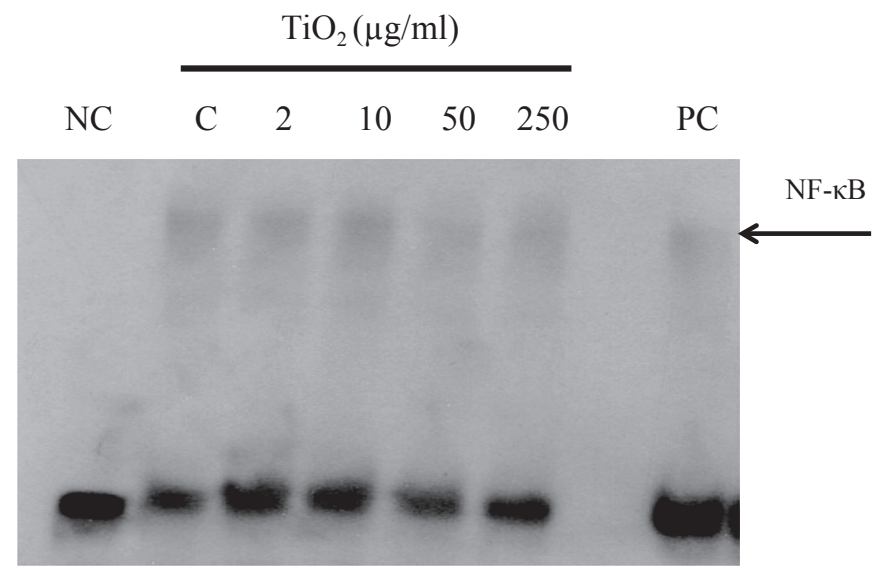

Fig. 3. Effect of $\mathrm{TiO}_{2} \mathrm{NPs}$ on NF-kB expression. After the A549 cells were incubated for 6 hours with and without $\mathrm{TiO}_{2} \mathrm{NPs}$, they were washed, scraped and pelleted, and the nuclear proteins were extracted. The extracted nuclear fraction was used for the determination of NF-kB by Electrophoretic Mobility Shift Assay (EMSA). This diagram is the representative EMSA gel at 6 hours of treatment with $\mathrm{TiO}_{2} \mathrm{NPs}$, on NF- $\mathrm{kB}$ expression. The NC lane represents the negative control for EMSA, $\mathrm{C}$ the control for treatment (No treatment), and the positive control (PC).

\section{Discussion}

IL-8 is an inflammatory chemokine that functions mainly as a chemo-attractant for leukocytes. Existing literature reveals that measurement of IL- 8 released from cultured cells is considered an indicator of inflammagenic potency of $\mathrm{TiO}_{2} \mathrm{NPs}[4,5]$. In this study, we showed that after 24 hours of exposure of A549 cells to $\mathrm{TiO}_{2} \mathrm{NPs}$, the level of IL-8 released increased in a statistically significant, $\mathrm{TiO}_{2}$ dose-dependent manner in the culture medium. These results are consistent with those of Singh et al [4] and Monteiller et al [5], suggesting that $\mathrm{TiO}_{2}$ NPs can induce inflammation in exposed cell lines.

We also found in this study that $\mathrm{TiO}_{2} \mathrm{NPs}$ did not cause an alteration in the expression of $\mathrm{NF}-\kappa \mathrm{B}$, a protein complex that controls the transcription of DNA. NF- $\kappa \mathrm{B}$ is considered a first responder to harmful cellular stimuli such as ROS [8], and the transcription of IL-8 is NF- $\kappa$ B de- 
pendent [9]. We investigated the effect of $\mathrm{TiO}_{2} \mathrm{NPs}$ on NF- $\kappa \mathrm{B}$ expression based on the fact that $\mathrm{TiO}_{2}$ NPs induce ROS production in A549 cells [4]. However, our negative findings suggest that $\mathrm{NF}-\mathrm{\kappa B}$ DNA binding is not the likely transcription pathway that leads to $\mathrm{TiO}_{2}$-induced inflammation.

Alternative explanations for these results can be made by examining other transcriptional factors associated with IL-8 protein release. It has been previously proposed that various motifs found on the 5-flanking region of the human IL-8 promoter have the potential to bind a number of important transcription factors [10]. Two of these factors, reported by Yong et al are Nuclear Factor Interleukin-6 (NF-IL-6), Activator Protein-1 (AP-1) [11]. Nagarsekar et al proposed the contribution of heat shock activated transcription factors (HSFs) [12]. Yong et al found that bradykinin, a non-cytokine mediator, caused IL-8 release from human airway smooth muscle (HASM) cells, and they suggested that NF- $\mathrm{BB}$ and other transcriptional factors, such as AP-1 and NF-IL-6, are likely to be involved in IL-8 release. Since IL-8 is also known to contain multiple heat-shock response elements (HSE)-like sequences, it is possible that IL-8 activation can also be mediated by HSFs $[12,13]$.

\section{Conclusion}

In conclusion, it is unlikely that NF- $\mathrm{BB}$ is involved in the inflammagenic ability of $\mathrm{TiO}_{2} \mathrm{NPs}$. However, our findings corroborate existing knowledge that $\mathrm{TiO}_{2} \mathrm{NPs}$ cause cellular inflammation. In view of our findings that NF- $\kappa \mathrm{B}$ expression was not affected, and on the aforementioned findings of previous studies, our future plan is to investigate the involvement of other transcriptional factors, namely AP-1, NF-IL-6 and HSFs, in $\mathrm{TiO}_{2}$-induced IL-8 release.

\section{Acknowledgements}

This study was jointly funded by a UOEH Research Grant for the Promotion of Occupational Health, No. H23 (平成23年度産業医学・産業保健重点研究費), and a UOEH Grant for Advanced Research, No. H21-H23 (平成21年度 23年度産業医科大学高度研究費).

\section{References}

1. International Agency for Research on Cancer (IARC) (2006): Titanium dioxide 93 5. Summary of data reported. [Online; cited January 7, 2012]. http://monographs.iarc.fr/ENG/Meetings/93-titaniumdioxide.pdf

2. Lam CW, James JT, McCluskey R \& Hunter RL (2004): Pulmonary toxicity of single wall carbon nanotubes in mice 7 and 90 days after intratracheal instillation. Toxicol Sci 77: 126-134

3. National Institute for Occupational Safety and Health (NIOSH) (2011): Occupational exposure to titanium dioxide. Current Intelligence Bulletin 63: 2-3 Available at url: http://www.cdc.gov/niosh/ docs/2011-160/.pdf

4. Singh S, Shi T, Duffin R et al (2007): Endocytosis, oxidative stress and IL-8 expression in human 
lung epithelial cells upon treatment with fine and ultrafine $\mathrm{TiO}_{2}$ : Role of the specific surface area and of surface methylation of the particles. Toxicology Appl Pharmacol 222: 141-151

5. Monteiller C, Tran L, MacNee W, Faux S, Jones A, Miller B \& Donaldson K (2005): The pro-inflammatory effects of low-toxicity low-solubility particles, nanoparticles and fine particles, on epithelial cells in vitro: the role of surface area. Occup Environ Med 64: 609-615

6. Donaldson K \& Stone V (2003): Current Hypotheses on the Mechanisms of Toxicity of Ultrafine Particles. Ann Ist Super Sanita 39: 405-410

7. Rahman I, Mulier B, Gilmour PS, Watchorn T, Donaldson K, Jeffery PK \& MacNee W (2001): Oxidant-mediated lung epithelial cell tolerance: the role of intracellular glutathione and nuclear factorkappa B. Biochem Pharmacol 62: 787-794

8. Perkins ND (2007): Integrating cell-signalling pathways with NF-אB and IKK function. Nat Rev Mol Cell Biol 8: 49-62

9. Sen CK (2000): Cellular thiols and redox-regulated signal transduction. Curr Top Cell Regul 36: 1-30

10. Choi EY, Park ZY, Choi EJ, Oh HM, Lee S, Choi SC, Lee KM, Im SH, Chun JS \& Jun CD (2007): Transcriptional regulation of IL- 8 by iron chelator in human epithelial cells is independent from NFkappa B but involves ERK1/2- and p38 kinase-dependent activation of AP-1. J Cell Biochem 102: $1442-1457$

11. Zhu YM, Bradbury DA, Pang L \& Knox AJ (2003): Transcriptional regulation of interleukin (IL)-8 by bradykinin in human airway smooth muscle cells involves prostanoid-dependent activation of AP-1 and nuclear factor (NF)-IL-6 and prostanoid-independent activation of NF-kappa B. Biol Chem 278: 29366-29375

12. Nagarsekar A, Hasday JD \& Singh IS (2005): CXC chemokines: a new family of heat-shock proteins? Immunol Invest 34: 381-398

13. Singh IS, Gupta A, Nagarsekar A, Cooper Z, Manka C, Hester L, Benjamin IJ, He JR \& Hasday JD (2008): Heat Shock Co-Activates Interleukin-8 Transcription. Am J Respir Cell Mol Biol 39: 235-242 
二酸化チタンナノ粒子が誘導する炎症反応に核内因子 $\kappa B$ B関与していない

ドナルドウィルソン ${ }^{1}$, マゼン ザクート1， ジョンフン ホー2， ユンキー パク3，

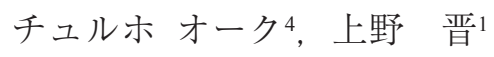

1 産業医科大学 産業生態科学研究所 職業性中毒学教室

2 韓国釜山市高神大学 医学部 分子生物学·免疫学部門

3 韓国釜山市高神大学 医学部 医療人文科学・社会医学部門

4 韓国釜山市高神大学 医学部 呼吸器内科部門

要旨：近年における研究によると, 二酸化チタン $\left(\mathrm{TiO}_{2}\right)$ ナノ粒子が肺, 腎臓, 肝臓および脳な ど様々な細胞で炎症反応を誘導することが示されている，その炎症反応が誘導されるメカニズム については未だ明らかとされていないが,これまでの文献によると酸化ストレスがその根本的な役 割を果たしていることが示唆されている。一方, 核内因子 $\mathrm{kB}(\mathrm{NF}-\mathrm{kB})$ が炎症性サイトカインに反応 して活性化されることも示されている。そこで本研究では, ヒト肺上皮腺癌 (A549) 細胞において, $\mathrm{TiO}_{2}$ が誘導する炎症反応にNF-kBが関与しているかを検討した. 24時間処理後におけるA549細胞 からのIL-8放出量は対照群と比較して, 10, 50 およ゙ $250 \mu \mathrm{g} / \mathrm{ml}$ のP $25 \mathrm{TiO}_{2}$ ナノ粒子において統計学 的に有意に増加した。 IL-8放出量の結果は, 報告された知見を裏付けるものである。しかしなが ら,P25で6時間処理した後のNF-kBのDNAへの結合性には影響を与えなかった. NF-kB検討の結 果から, NF-kBのDNAへの結合がTiO ${ }_{2}$ 誘導性の炎症反応を生じるための転写経路とは考えにくい.

キーワード : 二酸化チタンナノ粒子, $\mathrm{TiO}_{2}$, 炎症反応, $\mathrm{A} 549$ 細胞, $\mathrm{NF}-\mathrm{kB}$.

J UOEH（産業医大誌）34（2）：183 - 191（2012） 